\title{
Mining, Development and Indigenous Peoples
}

\author{
Ciaran O'Faircheallaigh \\ School of Government and International Relations \\ Griffith Business School \\ Griffith University \\ Nathan, Queensland 4116 \\ ciaran.ofaircheallaigh@griffith.edu.au
}

\section{Introduction}

For many Indigenous people, there is an inherent contradiction between mining and sustainability. For them, the values, technologies and impacts associated with large-scale extractive industries are incommensurate with maintenance of their identity and survival as Indigenous people, with their own 'sustainability'. In terms of values, the mining industry is ultimately driven by the search for profit. Indigenous values, while certainly requiring robust systems of economic production, regard the maintenance of the ancestral land and sea country which supports these systems, and the cultural, social and spiritual practices essential for their maintenance, as having priority over financial gain. Technologies of mineral production that can reshape landscapes, change river flows and generate pollution that harms people and lands far from sites of extraction are regarded as the antithesis of 'sustainability'. In the words of Yvonne Margarula, who led the Mirrar people’s fight against a second uranium mine on their traditional country in Australia's Northern Territory:

We do not feel that our people or our country have been protected since mining came here. Government has forced us to accept mining in the past and we are concerned that you will force mining development upon us again. Previous mining agreements have not protected us or given our communities strength to survive development. A new mine will make our future worthless and destroy more of our country. We oppose any further mining development in our country (cited in Laszlo 1997)

To make matters worse, decision making processes associated with large scale mineral development have marginalised Indigenous peoples, undermining their capacity to control what occurs on their ancestral lands, with negative consequences that go well beyond the immediate impact of mining (Evans, Goodman and Lansbury 2002; O’Faircheallaigh 2016, 42-46; Sawyer and Gomez 2012) .

In sum, many Indigenous people reject the fundamental proposition that there are circumstances in which mining can contribute to sustainable development. It would be misleading to start writing on the subject of 'Mining and Sustainable Development' in an Indigenous context without first acknowledging this point.

There are also Indigenous peoples who believe that mining can contribute to sustainable development of Indigenous peoples and communities, if it is conducted in a way that allows 
them to share substantially in its economic benefits and to control its social, environmental and cultural impacts (Bergmann 2010; Gibson Macdonald, Zoe and Satterfield 2014). The issue of Indigenous control is paramount. In my experience, and this is reinforced by the literature, very few Indigenous people trust corporations or state regulators to protect Indigenous interests. As I have noted elsewhere, in discussing the impact of colonisation in Australia and Canada, 'Aboriginal suspicion of the State, its motives and its actions is deeply entrenched' (O’Faircheallaigh 2016, 40; see also Coates 2004, 100-101, who makes the same point in relation to Indigenous peoples globally). This distrust of corporations and the State is, for example, fundamental to the sustained international campaign by Indigenous groups to achieve recognition of the principle of Indigenous Free Prior and Informed Consent (IFPIC), which requires that Indigenous peoples should be able to control whether development occurs on their lands and, if it does, what form it should take (O’Faircheallaigh 2012).

This chapter is written from the second perspective, that mining can in principle contribute to Indigenous development, but only if it is conducted in a way that gives Indigenous peoples the power to control its impact, and by so doing allows them to share in its benefits and minimise its costs. Given the importance of control, the chapter begins with a discussion of decision making in the extractive industries, and the Indigenous role (or lack of it) in making decisions about development on their ancestral lands. I then examine two specific issues that are central to the interaction between extractive industries, Indigenous peoples and sustainability. In relation to ecological sustainability, the chapter will illustrate the way in which Indigenous participation in environmental management of large resource projects serves to minimise their negative ecological impacts. This in turn contributes to the sustainability of Indigenous societies and to the mining industry's net contribution to sustainable development. In terms of economic sustainability, the focus is on the use of mineral revenues accruing to Indigenous peoples to promote economic and social development that can be sustained after mining ends.

In addressing the conditions necessary to drive innovation and reform that can help increase mining's contribution to sustainable development, I argue that these lie in arenas broader than the management of individual mining projects. What are required are system-wide approaches designed to enhance the ability of Indigenous peoples to engage with states and the mining industry on a basis of equality. In particular, progress in mobilising the ability of Indigenous people to help mining contribute to sustainable development requires state authorities to recognise and support the capacity of Indigenous peoples to shape the basis on which they interact with extractive industries.

\section{Sustainability and Indigenous control}

Historically, Indigenous people have had little control over mineral development on their lands. While the situation varied to some extent across the globe, until the 1970s virtually all Indigenous peoples, from the Amazon rainforest to the Australian desert, from the Canadian or Soviet Arctic to the Pacific islands, faced a similar situation. State authorities disposed of mineral resources on Indigenous lands, and corporations decided whether and how to develop them, with no reference to Indigenous peoples or their interests.

This situation resulted from the denial to most Indigenous people of civil and political rights and state failure to recognise their interests in land, both of which reflected dominant racist ideologies; their lack of numerical influence in most jurisdictions; and their remote location and lack of access to financial and technical resources. The degree of violence employed in 
dealing with them varied across countries and over time, but the end result for nearly all Indigenous peoples affected by mining was similar (Blaser et al. 2004; Coates 2004; Wilson 1998). They were dispossessed of their lands without compensation when these were required for mining, a reality which prevailed in Australia at least until the 1960s, and continues to prevail in parts of Asia, Africa and South America today (Bebbington and Bury 2013; Sawyer and Gomez 2012). They failed to share substantially in the wealth extracted from their ancestral lands, and indeed Indigenous populations in mineral-rich regions continue to be severely disadvantaged relative to their non-Indigenous neighbours (Langton and Mazel 2008). Their cultural heritage, including sites and areas of great spiritual significance, were destroyed with impunity, and they endured social impacts created by of large inflows of outsiders who generally had scant regard for their culture or values and often exploited them ruthlessly (Dixon and Dillon 1990). Richie Howitt's summary of the experience of Aboriginal people in Western Australia's Eastern Goldfields region - 'All they get is dust' could apply to Indigenous peoples globally (Howitt 1990).

Matters began to change, slowly and very unevenly, from the 1970s. In an initiative that was slow to be replicated elsewhere, in 1976 the Australian government passed land rights legislation ${ }^{1}$ that conferred on traditional owners of Aboriginal freehold land in the Northern Territory the right to reject or approve applications for exploration (and so ultimately for mining) licences. At about the same time, those Indian tribes in the United States which had been able to maintain ownership over mineral-rich lands and were recognised in law as 'dependent sovereign nations', such as the Navajo, threw off the bureaucratic control formerly exercised by the Bureau of Indian Affairs. They started to take their own decisions about development on their reserves and to deal directly with developers wishing to exploit energy and mineral resources (Jorgensen et al. 1978). Of critical importance in the context of this discussion, as soon as Indigenous people were able to exercise a measure of control, immediate and rapid change occurred in the share of benefits accruing to Indigenous landowners. In the Northern Territory for example within just two years of the passage of land rights legislation, Aboriginal traditional owners who had previously received no economic benefits from mining on their land negotiated royalty payments at levels comparable to those traditionally applied by state or national governments in mineral-rich jurisdictions ${ }^{2}$. Equally significant, traditional owners also negotiated substantial cultural heritage and environmental protections in addition to those available under state regulations (O’Faircheallaigh 2002). Perhaps most important of all, in numerous cases where they believed that mining would, on balance, not contribute to sustainable development, traditional owners refused to allow it to proceed (O’Faircheallaigh 1988).

Elsewhere, including in large parts of Australia and the United States, the legal rights of Indigenous people changed little. They did increasingly use other means, including media campaigns, direct action and building alliances with sympathetic non-Indigenous groups, to oppose mining projects they believed would threaten their livelihoods and their cultures. Groups in disparate countries including Brazil, the Soviet Union, Canada, Papua New Guinea, and Indonesia fought hard to control development, but in many cases their efforts ended in failure and, in developing countries, often in violent repression (Anguelovski 2008; Ballard 2001).

From the 1980s onwards, the efforts of individual Indigenous peoples were supplemented by a growing international Indigenous movement that sought recognition and protection of Indigenous rights in fora such as the United Nations, the International Labour Organisation (ILO) and the Inter-American Court of Human Rights. These efforts bore fruit with the 
adoption by the ILO of International Labour Office Convention 169 on the Rights of Indigenous Peoples. The Convention states that 'the rights of ownership and possession of the peoples concerned over the lands which they traditionally occupy shall be recognised' (Article 14), and that 'the rights of indigenous peoples to the natural resources pertaining to their lands shall be specifically safeguarded' (Article 15). The right to IFPIC is cited in relation to any proposed activities that require relocation of indigenous peoples, which should take place 'only with their free and informed consent' (Article 16.2). While only a small number of countries have adopted ILO 169 and while serious issues remain about its implementation, its adoption was an indication that change, however slow, was occurring in the relationship between Indigenous peoples, the State and extractive industries.

Over the last thirty years this change has continued. More Indigenous groups have been able to establish an ability to negotiate regarding the terms on which development may occur on their lands, though it is still the case today that very few have the ability to reject development if they consider its impact will render their societies unsustainable. For instance many groups in Australia, as a result of Federal recognition of inherent Indigenous rights in land through the Native Title Act 1993, and in Canada, through provisions of comprehensive land claim settlements, have a right to negotiate 'impact and benefit' agreements that provide for sharing of project benefits and additional impact mitigation measures. Even in countries where such legal rights do not exist, the political mobilisation of Indigenous peoples, in some cases combined with the adoption by extractive industries of 'corporate social responsibility' policies, are resulting in the negotiation of company - Indigenous agreements (Bebbington and Bury 2013; O’Faircheallaigh and Ali 2008; RESOLVE 2015).

However a 'right to negotiate' provides only an opportunity to pursue a degree of Indigenous control, it does not guarantee it. Mining companies, while often prepared to allocate at least some economic benefit to Indigenous groups, are generally very reluctant to enter agreements that give Indigenous people substantial control over the design or operation of mining projects. The result is that in only a small minority of cases where Indigenous groups are able to mobilise substantial organisational, political and reputational resources to place pressure on corporations are they able to achieve such control. For example the author's study of 45 Australian agreements found that in only a quarter were the Indigenous participants able to negotiate provisions that allowed them a substantial role in managing project environmental impacts or added significantly to the inadequate protection of Indigenous cultural heritage offered by state legislation (O’Faircheallaigh 2016, 83-96; see also O’Neill 2015).

In recent years the international movement for recognition of Indigenous rights has gathered momentum, culminating in the adoption by the United Nations General Assembly of the UN Declaration on the Rights of Indigenous Peoples in 2007. Indigenous control of development, through application of the principle of free prior informed consent (FPIC), constitutes a central element of the Declaration, as for example in Article 32:

1. Indigenous peoples have the right to determine and develop priorities and strategies for the development or use of their lands or territories and other resources.

2. States shall consult and cooperate in good faith with the indigenous peoples concerned through their own representative institutions in order to obtain their free and informed consent prior to the approval of any project affecting their lands or territories and other resources, particularly in connection with the development, utilization or exploitation of mineral, water or other resources. 
The Declaration is not legally binding on state authorities, and states that have adopted it continue in many cases to reject its principles. For example in Australia governments regularly use compulsory acquisition powers to acquire Indigenous land and force through projects without achieving the consent, and often against the active opposition, of Indigenous peoples (O’Faircheallaigh 2015, 54-55). In some developing countries, states continue to use repression and violence to that same end (Bebbington and Bury 2013; Sawyer and Gomez 2012). Neither is the Declaration binding on the extractive industries, and many companies still regard achievement of Indigenous consent as an aspiration rather than as a necessary precondition for investing in projects on Indigenous land (Papillon and Rodon 2017), though there are important exceptions in this regard (see for example Shell 2017, 49). The principle of FPIC and the UN Declaration do constitute an important legal and moral platform from which Indigenous people can assert their demands for control over development. However, the reality is that only where they can apply economic and political pressure on domestic decision makers can they achieve acceptance of these demands (O'Faircheallaigh 2012).

Despite some progress in recent decades, Ken Coates general summary of the situation regarding Indigenous control over land applies equally well to the specific case of mineral development: ' . .. even late-twentieth and early-twenty-first century efforts to establish a tiny measure of indigenous responsibility have made few inroads' $(2004,139)$. This constitutes a huge problem in terms of ensuring that mining contributes to sustainable development. It means that Indigenous people cannot stop projects that are inherently incapable of making such a contribution, and can only rarely insist on changes to project design and operation that might enhance the contribution of projects to sustainable development. I return to this point in discussing the conditions necessary to drive innovation and reform.

\section{Indigenous peoples and the environmental impacts of mining}

Managing the environmental impacts of mining represents an issue of critical importance both to the mining industry and Indigenous peoples. The cost to industry of failure to effectively manage environmental impacts is illustrated by other contributions to this volume. For Indigenous people the cost of failure is even greater in that it can destroy their livelihoods and social and cultural survival (Kirsch 2014). Given this context there are, in principle, strong incentives for industry and Indigenous peoples to cooperate to minimise mining's negative effects on the environment. Indigenous peoples are often in a unique position to assist mining companies in minimising negative environmental impacts and in rehabilitating mine sites to acceptable environmental standards.

One critical resource they possess is time depth in relation to information on the existing environment ('base line data'). Typically, mining companies only start collecting base line data which they use in assessing likely project impacts, in establishing acceptable impacts, and in designing environmental monitoring and management systems, some 2-3 years before project construction is planned to commence. The difficulty is that environmental conditions can be highly variable over time, and a few years' data may not provide a sufficient basis on which to develop an understanding of environmental dynamics. Indigenous landowners draw not only on decades of experience in observing environmental conditions, an understanding of which is vital to their subsistence activities, but also on generations of experience handed down to them. Thus their participation is essential in achieving a full and accurate understanding of existing environmental dynamics, which in turn is the foundation for effective environmental protection (Nadasdy 2003; Usher 2000). 
A second area involves the intimate and ongoing contact that many indigenous people have with their ancestral lands and waters. ${ }^{3}$ This can place them in an excellent position to assess what environmental impacts are likely to be most significant, and what measures are likely to be effective in avoiding or mitigating them. It also allows them to quickly detect ecological changes that may signal problems with a mine's environmental management system, helping to avoid potential damage. On one occasion the author, while travelling across country with traditional owners of a major mine in north Australia, encountered a small area of lush vegetation in a place that elders said would normally be dry at that time of year. They alerted mine management to what they believed was a leak of water from the mine's open pit into sub-surface drainage channels. The mine's environmental section initially rejected this possibility, stating that its extensive water monitoring system had not picked up any sign of water moving out of the open pit. After a subsequent visit to the area revealed a further increase in vegetation, the traditional owners insisted that the mine undertake additional investigations. These revealed that water was indeed leaving the open pit, and the company was able to take remedial action.

A range of more specific indigenous knowledge can also greatly assist effective environmental management. This can include understanding of animal and bird behaviour essential in devising effective wildlife monitoring and management regimes; and knowledge of the soil and drainage conditions required for specific plants to thrive, critical for successful rehabilitation of areas disturbed by mining and associated activities (O’Faircheallaigh 2010a).

Despite the obvious contribution Indigenous people could make in addressing a matter of enormous economic and political significance to the mining industry, in general mining companies fail to take advantage of Indigenous environmental knowledge. Indeed an extensive analysis of negotiated agreements in Australia indicates that the opposite is the case. Few companies using the opportunity agreements provide to secure indigenous participation, and some sought to use agreements to reduce Indigenous input below that allowed by environmental legislation (O’Faircheallaigh and Corbett 2005). These findings are consistent with the author's own experience in agreement negotiations and with Canadian research (Cragg and Greenbaum 2002: 321-322). Even where companies are prepared to accept provisions strongly favourable to Aboriginal landowners in areas such as financial compensation, cultural heritage protection, and employment and training, they tend to strongly resist sharing control over environmental management.

Reflecting this situation, in those few cases where Indigenous peoples do manage to influence project design and operations, this usually results from protracted negotiations that require Indigenous negotiators to overcome resistance from companies, and in some cases from state authorities. Two examples illustrate this point, and at the same time highlight the potential contribution of Indigenous people to ecological sustainability.

The first involves the Voisey's Bay nickel project in Labrador, Canada. Over a number of years the project's then owner, Inco Ltd, and the Province of Newfoundland and Labrador refused to accept proposals by the area's Indigenous owners, the Innu and Inuit, to reduce the scale of the project, to minimise its impact on marine ecosystems, and to enhance the effectiveness of ongoing environmental monitoring. Decreasing the scale of the project was seen as especially important by the Innu and Inuit. It would reduce the project's environmental footprint, for example by allowing shipping schedules to be organised to minimise impact on sea ice. It would also extend project life, allowing the Innu and Inuit 
more time to develop the skills and organisational capacity required to take advantage of development opportunities generated by the project. Reducing project scale would thus contribute simultaneously to ecological, economic and social sustainability. Only after the Innu and Inuit demonstrated their capacity to stop the project entirely through litigation and direct action did Inco and Newfoundland accept their environmental proposals. After Voisey's Bay achieved commercial production in 2006, complete with enhanced environmental protection and at less than half the size initially planned by Inco, it operated very profitably. This is especially significant given Inco's earlier assertions that the project would not be economically viable at the smaller scale demanded by the Innu and Inuit (O’Faircheallaigh 2016, 174-98).

The second example involves a Liquefied Natural Gas (LNG) project planned for a site north of Broome, in the Kimberley region of Western Australia (WA), by the WA State Government and a consortium of energy companies led by Woodside Energy Ltd (WEL). Here also the Aboriginal traditional owners and their regional organisation, the Kimberley Land Council, had to apply substantial financial, organisational and political resources in an extended negotiation before WA and WEL would accept a substantial Aboriginal role in environmental planning, monitoring and management. Measures ultimately included in project agreements with Aboriginal traditional owners included a requirement for WEL to build a water desalination plant if withdrawal of water from aquafers threatens significant environmental damage; and that the State must employ a compliance officer specifically for the LNG Precinct throughout its life, which could exceed 50 years, to monitor and ensure compliance with environmental conditions.

This last provision is highly significant given that state governments and other regulatory authorities have historically been ineffective in ensuring that environmental conditions continue to be monitored and enforced throughout project life (Morrison-Saunders and Arts 2005). In recent years their deficiency in this regard has worsened as governments have cut numbers of environmental inspectors and other regulatory staff in response to budgetary pressures and political demands for 'smaller government' and less 'green tape'. For example in 2012-2013 a newly elected conservative government in Queensland, one of Australia's largest mining states, eliminated 1,400 jobs across government departments dealing with environmental regulation, including those of 30 inspectors whose role was to check on resource development projects with environmental conditions attached. Similar trends are evident across the globe (Campbell 2009; Goodland 2012; Novaes and de Franca Souza 2013; Steinzor, Glicksman and Havemann 2014). In the case of Kimberley LNG, only Indigenous intervention ensured that monitoring of environmental of environmental compliance would be guaranteed throughout project life, with benefits not just for traditional owners but for the community as a whole.

At exactly the same time (2010-2011) as Kimberley Aboriginal Traditional Owners were negotiating these terms, similar LNG projects were being developed at Gladstone, in Central Queensland, by consortia that included some of the same energy companies involved in the Kimberley and under legislative provisions identical to those that applied in Western Australia. It is telling that in Gladstone, where Aboriginal landowners lacked the financial and political resources and the media profile enjoyed by their counterparts in the Kimberley, project agreements with traditional owners make no reference at all to environmental planning or management. This did not result from any lack of interest or environmental expertise on the part of the Gladstone traditional owners. They simply did not have the bargaining power to insist that industry allow them to have a role in improving the ecological 
sustainability of the projects involved, and so industry did not respond to their wish to play such a role (O’Faircheallaigh 2013; O’Neill 2015).

The reluctance of industry to afford Indigenous peoples a substantial role in environmental planning and management reflects a number of factors. One involves a general reluctance by project operators to have any external entity constrain their freedom of action in relation to aspects of project design and operations that can have a major impact on profitability and corporate reputation. Another may arise from the fact that Indigenous communities, or segments of those communities, may oppose mining projects, especially when they are initially proposed and before it is clear what their impacts might be. Companies may then suspect the motives of Indigenous leaders who insist on having a major say in environmental planning and management, fearing that they may use access to information they obtain through their participation to oppose a project on environmental grounds. But given the history of Indigenous - mining relations over many centuries, the mining industry cannot expect that Indigenous peoples will immediately welcome proposed mines with open arms. This does not mean that, if companies approach Indigenous communities with a willingness to engage and offer them a degree of control over what happens on their ancestral lands, they will not be prepared to contribute their knowledge and experience to enhance the ecological sustainability of mining projects. After all, Indigenous groups have a fundamental interest in achieving such an outcome. Finally, some company personnel may display racist or paternalist attitudes, assuming that Indigenous people have little of worth to contribute and that all wisdom resides with their own, conventional 'scientific' environmental expertise.

Industry leaders must take a role in changing attitudes towards the potential contribution of Indigenous people in reducing the environmental impacts associated with mining. Failure to do so will significantly reduce mining's net contribution to sustainable development, and at the same time leave the industry more exposed to environmental risks and their economic and reputational consequences.

\section{Mineral revenues and Indigenous development}

The issue of mining revenues and Indigenous development is contentious. Some analysts argue that it constitutes the critical mechanism through which extractive industries can contribute to the sustainable economic and social development of Indigenous peoples. Others, echoing the 'resource curse' literature, claim that mineral revenues foster dependency, cause social conflict and encourage waste and corruption. Elsewhere I have documented cases where Indigenous royalties are used to establish long-term investments funds that can generate an income after mining ends; to supplement inadequate education and health services; and to foster cultural activity and transmission of cultural knowledge (O’Faircheallaigh 2002, 2010b; see also Gibson Macdonald, Zoe and Satterfield 2010). Yet there are also many cases where Indigenous revenues have been misappropriated, used to fund substance abuse, or spent on short term consumption of consumer goods, in the process undermining cultural practices and social structures and relationships (O'Faircheallaigh 2002; Wild 2016). Thus mineral revenues have the potential to destroy, as well as to promote, sustainable development.

How mineral revenues are used is obviously a critical consideration, but another and prior point must be made in relation to mineral revenues and Indigenous development. While mines on Indigenous lands in some regions of Australia, Canada and the United States 
generate significant payments to Indigenous landowners, in other parts of those countries and more generally across the globe, Indigenous people are usually excluded from sharing in mineral revenues. For instance while certain communities in North Australia are entitled to royalty payments which rise with project revenues and receive millions of dollars annually, in the coal mining regions of central Queensland and New South Wales or in the gold producing regions of Western Australia, Aboriginal traditional owners typically receive fixed cash that represent only a tiny percentage of the value of minerals extracted from their land. For example one coal agreement in New South Wales provides for a single payment of $\$ 50,000$ from a project whose turnover exceeds $\$ 1$ billion. Internationally, very few Indigenous groups gain a significant share of project revenues. Company allocations in most cases consist of grants for projects that are typically selected by community relations departments with a view to generating positive publicity and deflecting opposition to the company, in part by maximising local political leverage. What an Indigenous community believes is most important for its long-term sustainable development is a secondary consideration (Ballard 2001; Cleary 2014; Kapelus 2002; Welker 2014).

An obvious but important implication of this situation is that if mineral revenues are to contribute to sustainable Indigenous development, the mining industry needs to direct a much larger share of wealth generated by mining to the Indigenous owners of land from which it is extracted, and to do so more evenly across regions and projects. The minority of mines that are require to allocate substantial revenue streams to Indigenous peoples continue to operate profitably, indicating that there is no conflict between this requirement and the economic viability of the industry.

Even if this change can be achieved, revenues must be applied productively if they are to contribute to economic development, and equitably if they are to support social and cultural sustainability. Both research on mining revenues and Indigenous peoples, and the wider 'resource curse' literature, indicate that the quality and integrity of the Indigenous institutions that receive mineral revenues will be critical if these goals are to be achieved. However existing writing on the subject is much less clear about how such institutions can be developed where they do not already exist (O’Faircheallaigh 2011, 22). This is a particularly pressing issue for Indigenous peoples because their existing institutions have usually been developed for purposes quite different to those involved in effectively managing mineral revenues. Substantial additional research is required in the area of institutional development at the interface between mining and Indigenous peoples, but the following points can be made.

First, it is not possible to create effective institutional arrangements for managing mineral revenues which operate in isolation from their wider social and political context. Rather, the quality of governance in relation to revenues will mirror the overall quality of governance in an Indigenous society. Yet the typical response of mining companies which make payments to Indigenous groups is to create separate, non-Indigenous institutional structures, such as charitable trusts or foundations, to manage these payments (see for example Strelein and Tran $2007,5)$. The substantial resources needed to create legal forms and to build personal and institutional capacity are then focused on these structures. Mining companies wish to create separate and 'dedicated' institutions in the expectation that these will ensure that revenues are used in ways that are 'productive' according to the company's set of values; help to protect its 'social licence to operate'; and do not reflect badly on its reputation. Broadly, this means that revenues should be used for 'community purposes', such as service provision and infrastructure, and to generate activity valued by the mining industry, for example formal 
employment and establishment of business enterprises (Kapelus 2002, 289; O’Faircheallaigh 2016, 120, 140, 142). However institutions created to reflect corporate rather than Indigenous values are inevitably fragile. In particular, their non-Indigenous legal forms and processes lack transparency to the community members for whose benefit they supposedly operate, and as a result they are vulnerable to exploitation by politically-astute Indigenous individuals and groups pursuing their own agendas.

A recent illustration of this problem is the Groote Eylandt Aboriginal Trust, which received millions of dollars annually in royalties from BHPBillition's manganese mine in Australia's Northern Territory. The Trust was established as a 'charitable' entity whose objectives are to 'use royalty payments and donations for the education benefit, welfare comfort and general advancement in life of the aboriginal people from time to time resident on Groote Eylandt ...'. However in a period of rapidly growing revenues due to rising mineral prices towards the end of the last decade, the Trust's office holders were able to siphon off millions of dollars of revenues for their personal use (Wild 2016). This occurred against a background where community members were not in a position, for instance, to monitor and understand the financial reports of the Trust's auditors who were raising warnings about patterns of expenditure a number of years before the problem became obvious to the community.

The mining industry's hopes of controlling Indigenous revenues by using familiar, nonIndigenous institutional forms are likely to prove illusory. It would be much better advised to help build the capacity of existing institutions whose operations are well understood by Indigenous people so that these institutions can take on the additional role of allocating and managing mineral revenues. Building capacity in this way takes time. One of the clear lessons from experience to date is that the prospects for successfully managing Indigenous revenues from mining are best when institution- building begins well before substantial revenues actually arrive. If work on developing institutions is only commencing at the time when payments begin to occur, political forces intent on immediately appropriating revenues are mobilised, causing internal competition and conflict. This atmosphere is far from conducive to the information provision, deliberation and negotiation that a community will need to identify broadly-accepted norms and processes on which to base effective long-term management of mining revenues. Preparations need to start well before a project becomes operational. This may be difficult to achieve, for mining companies and Indigenous communities. Both tend to be preoccupied with decisions about whether or not a project will be approved, with negotiation terms of a project agreement, and with managing the immediate effects of project construction. In addition, companies may be fearful of raising expectations regarding the size of revenue streams if they make an early start on building institutional capacity to manage them. But these challenges must be met, because the evidence is unequivocal that leaving institution building until a point where revenue streams have already commenced is a recipe for failure (O’Faircheallaigh 2002, 2010b).

A final point involves the wider participation of Indigenous people in state and corporate decision making processes regarding development on Indigenous lands. As noted earlier, until very recently, and still today in many places, Indigenous people are excluded from decision making on design, approval and operation of mining projects. Yet in common with all social groups, Indigenous people learn how to take informed and effective decisions by engaging in decision making. To the extent that Indigenous peoples have the opportunity to exercise decision making in relation to other aspects of mineral development, they will enhance their capacity to make the 'right' decisions, in terms of their own values and priorities, in allocating and managing mining revenues. 


\section{Innovation and reform}

The discussion so far highlights the fact that many of the world's Indigenous peoples have little opportunity to engage with the mining industry in ways that would enhance its contribution to sustainable development, including Indigenous development. For reasons explained in detail above, Indigenous control is central to any effort to change this situation. Against a background of prolonged marginalisation, dispossession and exclusion from decision making, Indigenous peoples are generally unwilling to commit to engagement with states and corporations designed to promote sustainable development unless there is a real measure of Indigenous over what happens on Indigenous lands. Another major issue is that governments and corporations have shown little inclination to willingly acknowledge the potential contribution of Indigenous people in enhancing sustainability.

Given this reality, innovation and reform that can help increase mining's contribution to sustainable development must involve systemic and fundamental change that allows Indigenous peoples to negotiate with companies and the state from a position of equality. Change at the level of corporate policy towards individual projects will not be sufficient. Such policy change is subject to reversal as a result of shifting corporate priorities, reflecting for example, declining commodity prices or changes in project ownership. In addition, state action is required to change key decision making processes that currently exclude Indigenous peoples , including those that allocate Indigenous land for mineral exploitation; decide whether or not projects should proceed; and determine project environmental conditions. More broadly, the political marginalisation and state repression applied to Indigenous people in many parts of the globe must cease.

From this perspective, a genuine commitment by government to the principles which underlie the UN Declaration and which would afford Indigenous peoples substantial control over development is essential. Such a commitment will not be easy to achieve. Across the globe governments are primarily concerned to facilitate smooth establishment of mining projects, and tend to see any attempt by Indigenous people to assert their right to control development as incompatible with this goal. State authorities must recognise that current models of governance in extractive industries are inadequate to the task of ensuring that mining is conducted in a way that gains the confidence of Indigenous people, and is consistent with principles of sustainable development. A basic change in the attitudes of political and corporate leaders towards Indigenous peoples is an essential first step, from condemning them as an 'obstacle to development', to seeing them an asset in the pursuit of sustainable development. At a more practical level, states and corporations must support the capacity of Indigenous to participate effectively in planning and managing mining projects on their traditional lands, in particular by helping to build Indigenous institutions that are autonomous and driven by Indigenous priorities. Only through such institutions can the potential of Indigenous people to help mining contribute to sustainable development be realised.

\section{Conclusion}

The weight of historical evidence is firmly on the side of those Indigenous people who take the view that mining is incompatible with their sustainable development and indeed with the survival of their Indigenous identity. For centuries the states and corporations that control 
mineral development did nothing to protect Indigenous interests, let alone to ensure that mining would contribute to Indigenous development. Little wonder that Indigenous peoples so often oppose development they are not in a position to control.

Where they do achieve a degree of control over mining, Indigenous peoples play a significant role in ensuring that the industry operates in a way that minimises its ecological impact and so increases its net contribution to sustainable development. Their role in this regard is rarely acknowledged by corporate and state decision makers and, partly as a result, Indigenous peoples continue to be excluded from decisions regarding development on their land across most of the globe. For the mining industry, this exclusion constitutes a wasted opportunity, and one it can ill afford.

Greater Indigenous control also brings with it an immediate increase in the share of revenues from mining that accrue to Indigenous peoples. This revenue does have the potential to contribute to their sustainable development, but only where they are able to build robust Indigenous institutions to allocate and use it. Industry and government can do much more to support Indigenous people in building such institutions, in part by resisting the temptation to try and impose non-Indigenous legal and institutional forms that offer them the illusion of control, but in reality are more likely to result in dissipation of valuable mineral revenues.

This returns us to the starting point for the chapter. Indigenous control of mining is the key to making it compatible with Indigenous sustainable development. Until corporations and states accept this reality, mining will in many cases act to undermine sustainable development, not promote it.

\section{References}

Anguelovski, I. (2008) "Environmental justice concerns with transnational mining operations: exploring the limitations of post-crisis community dialogues in Peru". In O’Faircheallaigh, C. and Ali, S. (eds) Earth Matters: Indigenous Peoples, Extractive Industries and Corporate Social Responsibility. Greenleaf Publishing, Sheffield, 198221.

Ballard, C. (2001) Human Rights and the Mining Sector in Indonesia: A Baseline Study prepared for the Mining Minerals and Sustainable Development Project of the International Institute for Environment. Australian National University, Canberra.

Bebbington, A. and Bury, J. eds (2013) Subterranean Struggles: New Dynamics of Mining, Oil and Gas in Latin America. University of Texas Press, Austin.

Bergmann, W. (2010) “Greens should not force poverty on traditional owners”, The Australian, 5 April available at /www.theaustralian.com.au/news/opinion/greensshould-not-force-poverty-on-traditional-owners/story-e6frg6zo-1225849632605. Accessed 27 March 2012

Blaser, M., Feit, H.A. and McRae, G. (2004) In the Way of Development: Indigenous Peoples, Life Projects and Globalization. Zed Books, London.

Campbell, B. (ed) (2009) Mining in Africa: Regulation and development. Pluto Press, London.

Cleary, P. (2014) “Native Title Contestation in Western Australia's Pilbara Region”. International Journal for Crime, Justice and Social Democracy 3, 3, 133-48.

Coates, K. (2004) A Global History of Indigenous Peoples: Struggle and Survival, Palgrave Macmillan. London. 
Cragg, W. and Greenbaum, A. (2002) "Reasoning about Responsibilities: Mining Company Managers on What Stakeholders are Owed”. Journal of Business Ethics 39, 319-335.

Dixon, R. and Dillon, M. eds (1990) Aborigines and Diamond Mining: the politics of resource development in the East Kimberley. University of Western Australia Press, Nedlands.

Evans, G., Goodman, J. and Lansbery, N. eds (2002) Moving Mountains: Communities Confront Mining \& Globalisation. Zed Books, London.

Gibson MacDonald, G., Zoe, J.B. and Satterfield, T. (2014) "Reciprocity in the Canadian Dene Diamond Mining Economy”. In Gilberthorpe, E. and Hilson, G. (eds) Natural Resource Extraction and Indigenous Livelihoods: Development Challenges in an Era of Globalization. Ashgate, Aldershot, 57-74.

Goodland, R. (2012) Responsible mining: The key to profitable resource development. Institute for Environmental Diplomacy and Security, University of Vermont, Burlington.

Howitt, R. (1990) "'All they get is the dust': Aborigines, mining and regional restructuring in Western Australia's eastern goldfields”. Economic and Regional Restructuring Unit Working Paper No 1, University of Sydney, Sydney.

Jorgensen, J.G., Clemmer, R.O., Little, R.L., Owens, N.J. and Robbins, L.A. (1978) Native Americans and Energy Development. Anthropology Resource Centre, Cambridge, Mass.

Kapelus, P. (2002) "Mining, Corporate Social Responsibility and the "Community": The Case of Rio Tinto, Richards Bay Minerals and the Mbonambi”. Journal of Business Ethics 39, 275-296.

Kirsch, K. (2013) Mining Capitalism: The Relationship between Corporations and Their Critics. University of California Press, Oakland.

Langton, M, and Mazel, O. (2008) "Poverty in the Midst of Plenty: Aboriginal People, the "Resource Curse” and Australia's Mining Boom”. Journal of Energy and Natural Resources Law 36, 1, 31-65.

Laszlo, S. (1997) Traditional owners say 'no' to Jabiluka uranium, available at https://www.greenleft.org.au/node/14464. Accessed 27 April 2016

Morrison-Saunders, A. and Arts, J. (2005) Assessing Impact: Handbook of EIA and SEA Follow-Up. Earthscan, London.

Nadasdy, P. (2003) Hunters and Bureaucrats: power, knowledge and aboriginal-state relations in the Southwest Yukon. UBC Press, Vancouver

Novaes, R. L. M., \& de Franca Souza, R. (2013) "Legalizing environmental exploitation in Brazil: The retreat of public policies for biodiversity protection”. Tropical Conservation Science 6, 4, 477-483.

Nwapi, C. (2011) "Legal and policy responses to environmental offences in relation to Alberta Oil Sands”. Resources 115, 1-9.

O’Faircheallaigh, C. (1988) "Land Rights and Mineral Exploration: The Northern Territory Experience”. Australian Quarterly 60, 1, 70-84.

O’Faircheallaigh, C. (2002), A New Model of Policy Evaluation: Mining and Indigenous People. Ashgate Press, Aldershot.

O’Faircheallaigh, C. (2010a) “CSR, the Mining Industry and Indigenous Peoples in Australia and Canada: From Cost and Risk Minimisation to Value Creation and Sustainable Development”. In Louche, C., Idowu, S.O. and Filho, W.L. (eds), Innovative CSR: From Risk Management to Value Creation. Greenleaf Publishing, Sheffield, 398-418.

O’Faircheallaigh, C. (2010b) “Aboriginal Investment Funds in Australia”. In Yi-chong, X. and Bahgat, G. (eds), The Political Economy of Sovereign Wealth Funds. Palgrave Macmillan, London, 157-176. 
O’Faircheallaigh, C. (2011) Use and Management of Revenues from Indigenous - Mining Company Agreements: Theoretical Perspectives. ATNS Working Paper No 1 http://www.atns.net.au/atns/references/attachments/ATNSWP1_2011_OFaircheallaig h.pdf. Accessed 3July 2017.

O’Faircheallaigh, C. (2012) “International Recognition of Indigenous Rights, Indigenous Control of Development and Domestic Political Mobilization”. Australian Journal of Political Science 47, 4, 531-46.

O’Faircheallaigh, C. (2013) "Extractive Industries and Indigenous peoples: A Changing Dynamic?”. Journal of Rural Studies 30, 20-30.

O'Faircheallaigh, C. (2015) "ESD and community participation: the Strategic Assessment of the proposed Kimberley LNG Precinct, 2007-2013”. Australasian Journal of Environmental Management 22, 1, 46-61.

O'Faircheallaigh, C. (2016) Negotiations in the Indigenous World: Aboriginal Peoples and Extractive Industry in Australia and Canada. Routledge, New York.

O’Faircheallaigh, C. and Ali, S. eds (2008) Earth Matters: Indigenous Peoples, Extractive Industries and Corporate Social Responsibility. Greenleaf Publishing, Sheffield.

O'Faircheallaigh, C. and Corbett, T. (2005) "Indigenous Participation in Environmental Management of Mining Projects: The Role of Negotiated Agreements". Environmental Politics 14, 5, 629-47.

O’Neill, L. (2015) “The Role of State Governments in Native Title Negotiations: A Tale of Two Agreements”. Australian Indigenous Law Review 18, 2, 29-42.

Papillon, M. and Rodon, T. (2017) "Proponent-Indigenous Agreements and the Implementation of the Right of Free, Prior Informed Consent in Canada". Environmental Impact Assessment Review 62, 216-24.

RESOLVE (2015) From Rights to Results: An Examination of Agreements between International Mining and Petroleum Companies and Indigenous Communities in Latin America. RESOLVE, http://solutions-network.org/site-fpic/files/2015/09/FromRights-to-Results-Sept-2015-FINAL-ENG.pdf. Accessed 10 June 2017

Sawyer, S. and Gomez, E.T. eds (2012) The Politics of Resources Extraction: Indigenous Peoples, Multinational Corporations and the State. Palgrave Macmillan, London.

Shell 2017. Shell Sustainability Report 2016, https://reports.shell.com/sustainabilityreport/2016/. Accessed 12 June 2017

Steinzor, R., Glicksman, R. L., \& Havemann, A. (2014) “EPA's retreat from enforcement will harm Chesapeake Bay”. http://progressivereform.org/articles/EPA_StrategicPlan_IssueAlert_1402.pdf. Accessed 17 June 2014

Strelein, L. and Tran, T. (2007) Taxation, trusts and the distribution of benefits under native title agreements. Australian Institute for Aboriginal and Torres Strait Islander Studies, Canberra.

Usher, P.J. (2000) “Traditional Ecological Knowledge in Environmental Assessment and Management”. Arctic 53, 2, 183-193.

Welker, M. (2014) Enacting the Corporation: An American Mining Firm in PostAuthoritarian Indonesia. University of California Press, Berkeley.

Wilson, J. (1998) The Earth Shall Weep: A History of Native America. Picador, London. Wild, K. (2016) "Rosalie Lalara, ex-public officer of Australia”s richest land trust, pleads guilty to \$475k theft”. ABC News, 29 March available at http://www.abc.net.au/news/201603-29/rosalie-lalara-ex-land-trust-official-pleads-guilty-475k-theft/7282378. Accessed 2 May 2016 
${ }^{1}$ The Aboriginal Land Rights (Northern Territory) Act 1976.

${ }^{2}$ Early agreements in the Northern Territory provided for royalties of between 3.5 and 4.5 of the value of minerals produced, at least on a par with rates charged in most mineral-rich countries, states or provinces at that time.

${ }^{3}$ This discussion draws on O'Faircheallaigh 2010a. 